\title{
Seroimmunological study of Toxoplasmosis in Sheep in Babylon Province
}

\author{
M. H. AL-Hasnawy \\ Coll. of Vet. Med./ Unive Babylon
}

Abstract

The study was carried out to determine the seroprevalence of Toxoplasmosis in sheep in Babylon province by use of two methods (latex agglutination test (LAT) and Enzyme linked immunsorbant assay (ELISA)). The results of Latex agglutination were appeared infection rate of $13.77 \%$ (31 out of 225 animals), the higher seropositivity was in urban region $19.4 \%$ while in rural region it was $11.39 \%$, and depending on sex of animal thus higher rate in males were $16.51 \%$ compared with females $11.2 \%$, so the results were referred to higher rate in young ages (less than one year) were $22.41 \%$, and higher titer for latex agglutination test was 64 with rate $35.48 \%$.With respect ELISA test where the results referred to that out of 31 positive samples for LAT, nine samples were positive for IgG $29.03 \%$.

\section{Introduction}

Toxoplasma gondii is an intracellular protozoan which infect man and wide range of worm blooded animals including mammals and birds (7).Among the livestock ,sheep and goat are the more widely infected with $T$. gondii (16).In sheep ,the infection occur via ingestion of infective stage (oocyst) excreted from cats, and cause serious reproductive problems and economic losses(2), and has been recognized as a significant cause of lambing loss (11).The

\section{Materials \& Methods}

The present study was undertaken in Babylon province from June to September 2011. Two hundreds and twenty five heads of sheep of different sexes and ages were sampled from two rural areas (Al-Qasim and Abu-Gharaq) and one urban area (Hilla city).

\section{Blood sampling}

The blood samples were collected from jugular vein of each animal in vacuum tube without anticoagulant $(10 \mathrm{ml})$,then the tubes placed in cool box and transported to the laboratory, after clotting, the samples were centrifuged at $2000 \mathrm{rpm}$ for 10 minute, the serum was decanted and stored in eppendorf tube at $-20 \mathrm{C}^{\circ}$ until analysis.

\section{Serological analysis}

Two serological tests were used for the detect of antibodies to Toxoplasma gondii, including (LAT) latex agglutination test and seroprevalence surveys are main way to determine the distribution of disease by using many serological tests including (LAT) latex agglutination test, ( IFAT) indirect fluorescent antibody testand (ELISA)enzyme linked immunosorbent assay (20,13). The present study was carried out to determine the of seropositivity to Toxoplasma gondii in sheep in some rural and urban regions of Babylon province.

(ELISA) enzyme linked immunesorbant assay .

1- Latex agglutination test (LAT)

The commercial kit Toxo-latex ${ }^{\circledR}$ (Linear Chemicals S.L., Spain) was used for examine all collected sera according to manufactures instructions, the titer above 4 was considered as positive.

2- Enzyme linked immunesorbant assay (ELISA)

To determine $\mathrm{IgG}$, all positive sera for Latex Agglutination Test were examined in ELISA, by using commercial kit EIA IgG® ( ACON laboratories. Inc. USA) by using ELISA reader (Bio Tek, Instruments Inc, USA), the concentration of $10 \mu \mathrm{l}$ was considered as cut off value according to manufactures instructions.

3- Statistical analysis 
$\begin{array}{llll}\text { AL-Qadisiya Journal of Vet.Med.Sci. } \quad \text { Vol./11 } & \text { No./2 }\end{array}$

The results of seroprevalence for Toxoplasma gondii was statistically analyzed

by T-test according to excel 2007 software.

\section{Results and Discussion}

The results showed that out of 225 examined sheep ,31 were positive to Latex agglutination test in percentage of $13.77 \%$ this result is close nearly with other authors including , Ramzan (17), Dubey (6), Hoghooghi-Red (10), and Weitzman (22) in many countries including Pakistan, north America, Khoozestan, and Niger were recorded a percentage of $11.2 \%, 12.1 \%$, $13.8 \%$, and $14 \%$ respectively, while little higher values recorded by (1) in Iran, (15) in brazil, and (12) in Pakistan were recorded $18 \%, 18.75 \%, 19.88 \%$ respectively. The seropositivity in sera collected from sheep reared in rural regions was $11.39 \%$, while it

was $19.4 \%$ in animals reared in urban regions ,the cause may be due to high density of feral cat population in urban areas compared with rural areas where the movement is more restricted due to the dogs which accompanied sheep flocks either in house or pasture (8).According to sex of sheep, the results showed that the seropositivity in males was significantly $(\mathrm{P} \leq 0.01 \quad)$ more than seropositivity in females in percentage ratio of $16.51 \%$ and $11.2 \%$ respectively as demonstrated in table 1, These results are in agreement with others such as $(19,12)$ in Brazil and Pakistan respectively .

Table (1) : reveal the seropositivity of toxoplasmosis according to sex of animals

\begin{tabular}{|c|c|c|c|}
\hline Sex & Examined & Positive & percentage \\
\hline Males & 109 & 18 & 16.51 \\
\hline Females & 116 & 13 & 11.2 \\
\hline Total & 225 & 31 & 13.77 \\
\hline
\end{tabular}

Table (2) reveal the influence of age on seropositively, the positive sera of animals aged less than 1 year ,1-2years and above 2 years were $22.41 \%, 22.22 \%$ and $5.3 \%$ respectively as presented in table 2 . The high prevalence in younger animals may be due to influence of immunity and management for young stocks, this in agreement with $(23,21,12)$.

Table (2): reveal the relation of age on seropositively

\begin{tabular}{|c|c|c|c|}
\hline Age (year) & No. examined & $\begin{array}{c}\text { No. positive } \\
\text { sera }\end{array}$ & percentage \\
\hline Less 1 & 58 & 13 & 22.41 \\
\hline $1-2$ & 54 & 12 & 22.22 \\
\hline Above 2 & 113 & 6 & 5.3 \\
\hline Total & 225 & 31 & 13.77 \\
\hline
\end{tabular}

In latex agglutination test ,the frequencies of different titers were presented in table 3, the highest percentage was titer 64 (35.48\%) followed by titers $32,16,128$ and
8 in percentage rate of $25.8 \%, 19.35 \%$, $12.9 \%$ and $6.45 \%$ respectively, these results are obtained by $(4,24)$ in Korea and Pakistan respectively . 
$\begin{array}{llll}\text { AL-Qadisiya Journal of Vet.Med.Sci. } \quad \text { Vol./11 } & \text { No./2 }\end{array}$

Table (3): reveal the frequency of titers in different animal categories

\begin{tabular}{|l|c|c|c|c|c|}
\hline \multirow{2}{*}{$\begin{array}{l}\text { Animal } \\
\text { Category }\end{array}$} & \multicolumn{5}{|c|}{ Titer frequency } \\
\cline { 2 - 6 } & 8 & 16 & 32 & 64 & 128 \\
\hline Male & 1 & 2 & - & 2 & - \\
\hline Female & - & - & 2 & 2 & - \\
\hline Less 1 year & - & 1 & 1 & 1 & 3 \\
\hline 1-2 years & - & - & 1 & - & 1 \\
\hline Above 2years & - & - & 2 & 1 & - \\
\hline Rural & 1 & 1 & 2 & 2 & - \\
\hline Urban & - & 2 & - & 3 & - \\
\hline Total no.(\%) & 2 & 6 & 8 & 11 & 4 \\
\hline
\end{tabular}

According to type of immunoglobulin ,out of 31 sera positive to latex agglutination test , 9 were $\mathrm{IgG}$ as resulted from examination with IgG ELISA kit in percentage of $29.03 \%$, these results were in agreement with (18) in Morocco, (3) in Mexico, (5) in Rio grande do Norte, (9) in Ardabil, and (14) in Sao Paulo and recorded prevalence were 27.6, 29.1, 29.4, 30, and $31 \%$ respectively.

\section{References}

1. Bonyadian, M. F., Hematzade and Manuchehri, K. (2007). Seroprevalence of antibodies to Toxoplasma gondii in sheep in center of Iran. Pakistan J. Biol. Sci., 10: 3228- 3230.

2. Buxton, D.S., Maley, W., Wright, S.E., Rodger, S., Bartleyand, P., Innes, E.A, (2007). Toxoplasma gondii and ovine toxoplasmosis: new aspects and old story. Vet Parasitol., 149: 25-28.

3. Caballero-Ortega, H., Palma, J.M., Garcı'aMa' rquez, L.J., Gildo-Ca' rdenas, A., Correa, D., (2008b). Frequency and risk factors for toxoplasmosis in ovines of various regions of the State of Colima, Mexico. Parasitology 135, 13851389.

4. Choi, W.Y., Yoo,J.E., Nam,H.W., Oh,C.Y., Kim,S.W., Katakura, K., and Kobayashi, A. (1987). Toxoplasma antibodies by indirect latex agglutination tests in zoo animals. Korean J Parasitol. 1987 Jun;25(1):13-23.
5. Clementino, M.M., Souza, M.F., Andrade Neto, V.F., (2007). Seroprevalence and Toxoplasma gondii-IgG avidity in sheep from Lajes. Brazil. Vet. Parasitol. 146, 199-203.

6. Dubey, J.P., and Foreyt, W.J., (2000). Seroprevalence of Toxoplasma gondii in Rocky Mountain big horn sheep (Ovis canadiansis). J. Parasitol, 86(3): 622-623.

7. Dubey, J.P., Webb, D.M., Sundar, N., Velmurugan, G.V., Bandini, L.A., Kwok, O.C., Su, C., (2007). "Endemic avian toxoplasmosis on a farm in Illinois: clinical disease, diagnosis, biologic and genetic characteristics of Toxoplasma gondii isolates from chickens (Gallus domesticus), and a goose (Anser anser)". Vet. Parasitol. 148 (3-4): 207-12.

8. Frenkel, J.K., Dubey, J.P., and Miller, N.L., (1970). Toxoplasma gondii in cats: faecal stages identified as coccidian oocysts. Science, 167: 893-896. 
$\begin{array}{llll}\text { AL-Qadisiya Journal of Vet.Med.Sci. } & \text { Vol./11 } & \text { No./2 }\end{array}$

9. Ghazaei, C., (2005). Serological survey of antibodies to Toxoplasma gondii. Afr. J. Health Sci. 12, 114117.

10. Hoghooghi-Rad, N., Afraa, M., (1993). Prevalence of toxoplasmosis in humans and domestic animals in Ahwaz, Capital of Khoozestan Province, South-West Iran. J. Trop. Med. Hyg. 96 (3), 163-168.

11. Innes, E.A, P.M., Bartley, D., Buxton, and Katzer, F., (2009).Ovine toxoplasmosis. Parasitology, 136: 1884-1887.

12. Lashari, M.H., and Tawasar, Z., (2010). Seroprevalence of Toxoplasmosis in sheep in Southern Punjab, Pakistan. Pak. Vet., 30(2):91-94.

13. Malik, M.A., Dreesen, D.W., and Cruz, A., (1990).Toxoplasmosis in sheep in north Eastern United States. J. Am. Vet. Med. Assoc., 196: 263265.

14. Meireles, L.R., Galisteo, A.J., Andrade, H.F., (2003). Serological survey of antibodies to Toxoplasma gondii in food animals from $\mathrm{Sa}^{\sim}$ Paulo state, Brazil. Braz. J. Vet. Res. Anim. Sci. 40, 267-271.

15. Pita Gondim, L.F., Barbosa, H.V., Rebeiro Filho, C.H.A., Saeki, H., (1999). Serological survaynof antibodies to Toxoplasma gondii in goats, sheep, cattle, and water buffaloes in Bahia state, Brazil. Vet. Parasitology.276-273 .82

16. Radostits, O.M. , Blood, D.C. and Gay, C.C. (1997). Veterinary Medicine: Textbook of the disease of cattle, sheep, pigs, goats and horses. $8^{\text {th }}$ ed. Saunders company Ltd. London. U.K.: 1306-1308.

17. Ramzan, M., Akhtar, M., Hussain, I., Muhammad, F., Hiszczy skaSawickaa, E., Haq, A.U., and Mahmood, M.S., (2008). Seroprevalence of Toxoplasma gondii in sheep and goats in area of Rahim Yar Khan (Punjab), Pakistan. 13th International Congress of Infectious Diseases, 19th June, Kuala-Lumpur, Malaysia, 5: 339.

18. Sawadogoa, P., Hafida, J., Belletec, B., Tran Manh Sunge, R., Chakdid, M, Floric, P., Raberinc, H., Bent Hamounia, I., Chaita, A., and Dalala, A. (2005). Seroprevalence of $T$. gondii in sheep from Marrakech, Morocco. Veterinary Parasitology Volume 130, Issues 12, 10 June 2005, Pages 89-92.

19. Silva, A.V., Da Cunha, E.L.P., Meireles, L.R., Gotschalk, S., Mota, R.A., and Langoni, H., (2003). Sheep and goat toxoplasmosis: seroepidemiological study in two regions in the State of Pernambuco, Brazil. Cienc. Rural., 33: 115-119.

20. Uggla, A., Beskew, P., Schwan, O., Bergguist, N.R., and Waller, T., (1983). Ovine toxoplasmosis in Sweden. Acta. Vet. Scand., 24: 113-119.

21. Vesco, G., Buffolano, W., La-Chiusa S., Mancuso, G., Caracappa, S., Chianca, A., Villari, S., Curro, V., Liga, F., and Petersen, E., (2007). Toxoplasma gondii infections in sheep in Sicily, Southern Italy. Vet. Parasitol, 146: 199-203.

22. Weitzman, G.L., Stem, E., Gilfillan, R.S., Lindenmayer, J.M., (1991). Preliminary serological survey for bluetongue and toxoplasmosis in sheep in Niger. Trop. Anim. Health Prod. 23, 258-1258.

23. Yung, R.L., (2000). Changes in immune function with age. Rheum Dis Clin North America, 26: 455-473.

24. Zaki, M., (1995). Seroprevalence of Toxoplasma gondii in domestic animals in Pakistan. J. Pak. Med. Assoc.;45(1):4-5. 
$\begin{array}{llll}\text { AL-Qadisiya Journal of Vet.Med.Sci. } \quad \text { Vol./11 } & \text { No./2 }\end{array}$

\section{دراسة مصليه مناعية لاءع المقوسات في أغنام محافظة بابل}

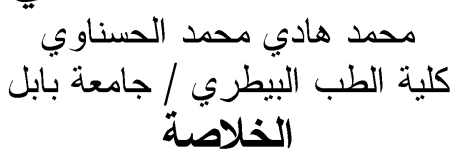

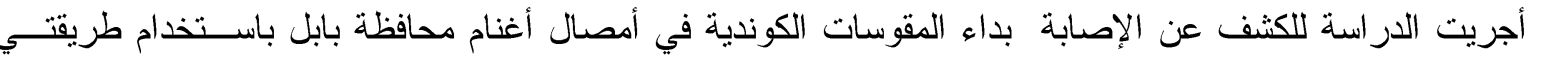

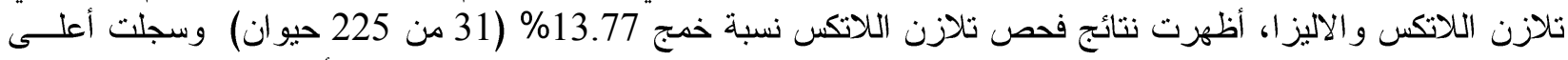
نسبة للخمج في المناطق الحضرية 19.4\% في حين كانت النسبة في المناطق الريفية 11.39\%ة 13.

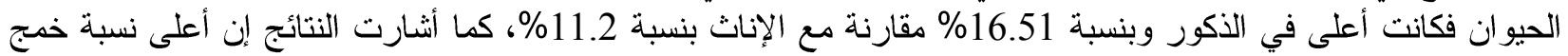

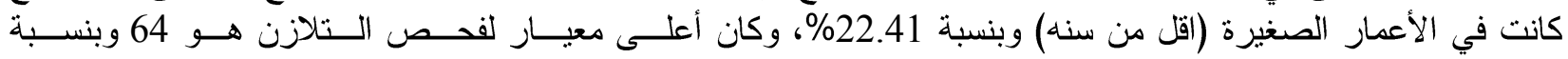

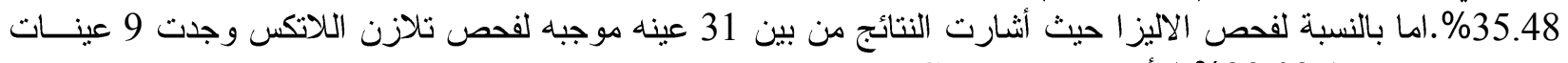

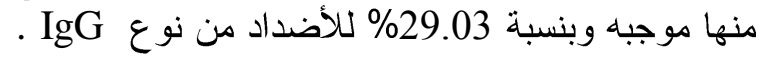

